\title{
The chromatin structure of the lysozyme GAS41 origin of DNA replication changes during the cell cycle
}

\author{
KATRIN ZIMMERMANN, MARLIS HOLTZ and LOC PHI-VAN ${ }^{1}$
}

Institute for Animal Welfare and Animal Husbandry, Federal Agricultural Research Centre, Dörnbergstr. 25-27, 29223 Celle, Germany

\begin{abstract}
We used a rapid and simple protocol using lysolecithin for mapping HS sites in vivo. The protocol is based on partial digestion with DNase I of exponentially growing cells following permeabilization by short treatment with lysolecithin. Using this protocol, we analyzed the chromatin structure of the region surrounding two overlapping elements, an origin of bidirectional DNA replication and the GAS41 promoter, in chicken myelomonocytic HD1 1 cells arrested in $G_{0}, G_{1}$ and $S$ phases as well as at the $G_{1} / S$ border. The results show that the chromatin of this region became more nuclease sensitive when cells were arrested in $G_{1}$ phase and that this change in chromatin structure was reversible after the cells began to enter $\mathrm{S}$ phase.
\end{abstract}

Key terms: chromatin structure, origin of bidirectional replication, Lysozyme, GAS41, promoter.

\section{INTRODUCTION}

Most of the chromosomal DNA in the nucleus of eukaryotic cells is tightly packaged. In contrast, actively transcribed genes are packaged into an altered chromatin structure characterized by a variety of features including increased sensitivity to nucleases, numerous hypersensitive sites (HS) known as local openings of the chromatin, decreased level of DNA methylation, histone acetylation etc. (Elgin, 1995). HS sites are usually smaller than $400 \mathrm{bp}$ and mostly located in the 5' flanking region of actively transcribed genes. The accessibility of chromosomal DNA to nuclear proteins such as transcription factors etc. is thought to occur preferentially at these sites. Indeed, in many cases, they are often co-mapped with regulatory DNA elements of known functions including promoters, transcriptional enhancers, hormone response elements, origins of DNA replication etc. (Elgin, 1988). HS sites are mapped in vitro by partial digestion of isolated nuclei with DNase I followed by indirect end-labelling (Hewish and Burgoyne, 1973; Wu, 1980). The chicken lysozyme-GAS41 (glioma-amplified sequence 41) locus contains numerous HS sites, some of which are mapped to regulatory elements important for the regulation of lysozyme expression in macrophages as well as during the differentiation of the oviduct (Fritton et al., 1987; Steiner et al., 1987; Jägle et al., 1997) and two closely spaced sites are associated with two overlapping elements, an origin of DNA replication (OBR) and the promoter of the downstream located GAS41 gene (Phi-van et al., 1998; Phi-van and Strätling, 1999; Zimmermann et al., 2002). In this study, we used lysolecithin to permeabilize intact cells to map the HS sites located within the $\mathrm{CpG}$ island between the lysozyme and GAS41 genes in myelomonocytic HD11 cells in vivo. Using this procedure, we further show that the chromatin of OBR/GAS41 promoter region changes and becomes more sensitive in cells arrested in $G_{1}$ phase of the cell cycle.

\footnotetext{
${ }^{1}$ Corresponding author: Loc Phi-van, Institute for Animal Welfare and Animal Husbandry, Federal Agricultural Research Centre, Dörnbergstr. 25-27, 29223 Celle, Germany, Phone: 49-5141-3846160, Fax: 49-5141-3846117, E-mail: loc.phi-van@fal.de
} 


\section{METHODS}

\section{Cell culture and cell synchronization}

HD11 cells (Beug et al., 1979) were maintained in Iscove's modified Dulbecco's medium (IMDM), supplemented with $8 \%$ fetal calf serum (FCS), 2\% chicken serum, $100 \mathrm{U} / \mathrm{ml}$ penicillin and $100 \mu \mathrm{g} / \mathrm{ml}$ streptomycin (complete IMDM) under 5\% $\mathrm{CO}_{2}$ at $37^{\circ} \mathrm{C}$. For synchronization, cells were grown in $15 \mathrm{~cm}$ diameter dishes $\left(2 \times 10^{7}\right.$ each) to $80-90 \%$ confluence, arrested in $\mathrm{G}_{0}$ phase by maintenance in IMDM without FCS and chicken serum for at least 48 hours, and then incubated in complete IMDM for 4 hours for entering $G_{1}$ phase. $G_{0}$-arrested cells were transferred to complete IMDM containing $20 \mu \mathrm{g} / \mathrm{ml}$ aphidicolin (Sigma, Deisenhofen, Germany) and maintained for at least 12 hours to accumulate at the $G_{1} / S$ boundary. To enter $S$ phase, $G_{1} / S$-arrested cells were washed twice in complete IMDM to remove aphidicolin and subsequently incubated at $37^{\circ} \mathrm{C}$ for 3 hours. Alternatively, serum- starved cells were returned to complete IMDM containing $400 \mu \mathrm{M}$ mimosine (Sigma, Taufkirchen, Germany) for at least 12 hours for accumulation in late $\mathrm{G}_{1}$ phase. The synchronized cells were controlled by flow-cytometric analysis. Briefly, trypsinized cells were stained with $10 \mu \mathrm{g} / \mathrm{ml}$ Hoechst 33342 for 15 minutes at $37^{\circ} \mathrm{C}$ and analyzed using a MoFlo ${ }^{\mathrm{TM}}$ from DakoCytomation (Hamburg, Germany).

\section{In vivo mapping of hypersensitive (HS) sites}

Cells washed once in phosphate-buffered saline (PBS) were permeabilized in $4 \mathrm{ml}$ of solution 1 containing $150 \mathrm{mM}$ sucrose, 80 $\mathrm{mM} \mathrm{KCl}, 35 \mathrm{mM}$ HEPES ( $\mathrm{pH}$ 7.4), $5 \mathrm{mM}$ $\mathrm{K}_{2} \mathrm{HPO}_{4}, 5 \mathrm{mM} \mathrm{MgCl}, 0.5 \mathrm{mM} \mathrm{CaCl} 2$ and $0.05 \% \quad$ L- $\alpha$-lysophosphatidylcholine (lysolecithin) (Sigma, Taufkirchen, Germany) for $1 \mathrm{~min}$ at $37^{\circ} \mathrm{C}$. Following washing once in $10 \mathrm{ml}$ of solution 1 without lysolecithin, cells were incubated in $4 \mathrm{ml}$ of solution 2 containing $150 \mathrm{mM}$ sucrose, 80 $\mathrm{mM} \mathrm{KCl}, 35 \mathrm{mM}$ HEPES ( $\mathrm{pH}$ 7.4), $5 \mathrm{mM}$ $\mathrm{K}_{2} \mathrm{HPO}_{4}, 5 \mathrm{mM} \mathrm{MgCl}, 2 \mathrm{mM} \mathrm{CaCl} \mathrm{Cl}_{2}$ and 100 to 500 units DNase I for $5 \mathrm{~min}$ at room temperature. After removal of the DNase I solution, cells were lysed immediately in solution 3 containing $0.3 \mathrm{M} \mathrm{NaCl}, 50 \mathrm{mM}$ Tris- $\mathrm{HCl}$ (pH 8.0), $25 \mathrm{mM}$ EDTA, $0.2 \%$ SDS and $0.2 \mathrm{mg} / \mathrm{ml}$ proteinase $\mathrm{K}$, followed by incubation at $37^{\circ} \mathrm{C}$ overnight. The resulting probe was extracted twice with phenol/chloroform/isoamyl alcohol (12:12:1), once with chloroform/isoamyl alcohol (24:1), and precipitated with ethanol. After centrifugation, the pellet was washed with $80 \%$ ethanol, dried under vacuum and dissolved in TE $[10 \mathrm{mM}$ Tris- $\mathrm{HCl}(\mathrm{pH} 7.5)$ and $1 \mathrm{mM}$ EDTA]. The probe was digested with $50 \mu \mathrm{g} / \mathrm{ml}$ RNase A for 2.5 hours at $37^{\circ} \mathrm{C}$, followed by treatment with proteinase $\mathrm{K}$ for 2 hours at $37^{\circ} \mathrm{C}$ and extraction with phenol/chloroform/isoamyl alcohol. Then, DNA was precipitated with ethanol, dried under vacuum and dissolved in TE. HS sites were mapped by the technique of indirect end labelling (Wu, 1980). Briefly, $10 \mu \mathrm{g}$ DNA were digested with HindIII, and fragments were resolved by electrophoresis on $1 \%$ agarose gels run in TPE [36 mM Tris, $30 \mathrm{mM} \mathrm{NaH}{ }_{2} \mathrm{PO}_{4}(\mathrm{pH} 8.0)$, and $1 \mathrm{mM}$ EDTA] and transferred onto nylon membranes by standard procedures (Southern, 1975). Then, the membranes were hybridized to $\mathrm{P}^{32}$-labeled probe $\mathrm{CeH} 10$ to map HS sites from the downstream located Hind III site as described previously (Phivan and Strätling, 1999).

\section{In vitro mapping of $H S$ sites}

For in vitro mapping of $\mathrm{HS}$ sites, nuclei from HD11 cells were digested with 150 units/ml DNase I as described previously (Phi-van and Strätling, 1999). DNA from digested nuclei was isolated, and HS sites were mapped using probe $\mathrm{CeH} 10$ as described above.

\section{RESULTS}

\section{In vivo mapping of $H S$ sites}

We have previously mapped the OBR located between the lysozyme gene and the immediately downstream located GAS41 gene (Zimmermann et al., 2002). Besides overlapping with GAS41 promoter, the 
OBR is associated with two closely spaced HS sites separated by $\sim 100 \mathrm{bp}$. These sites were mapped in vitro by the technique of indirect end- labeling following digestion of isolated nuclei from exponentially growing cells with DNase I (Hewish and Burgoyne, 1973; Wu, 1980). In this study, we analyzed the chromatin structure in vivo by a mapping procedure using intact cells. For this purpose, adherently growing HD11 cells were permeabilized by treatment with lysolecithin and then digested with increasing concentrations of DNase I. Following digestion of purified genomic DNA with HindIII, the HS sites were mapped by indirect end-labeling from the downstream located HindIII restriction site (H10) (see map in Fig. 1A). As shown in Figure 1B, hybridization of the Southern blot with probe $\mathrm{CeH} 10$ revealed HS sites dependent on DNase I concentrations. Prominent HS sites were obtained when DNase I at the concentration of 250 units/ $\mathrm{ml}$ was used, whereas most of DNA was digested by 500 units/ml DNase I. Figure $1 \mathrm{~B}$ shows further that in addition to the upstream located prominently appearing HS sites at the OBR and the GAS41 promoter three other HS sites are present in the coding region of the GAS41 gene. Thus, these results are consistent with those obtained from the in vitro mapping using isolated nuclei (Fig. 1C).

\section{Sensitivity of GAS41 promoter/OBR chromatin in cells arrested in G1 phase}

Using the presently described procedure we analyzed the chromatin structure of the OBR/GAS41 promoter region during the cell cycle. Starvation of cells for serum induced arrest of cells in Go phase, and the Go-arrested cells were then re-fed with complete medium for entering $G_{1}$ phase or with complete medium containing aphidicolin, a potent inhibitor of DNA polymerase $\alpha$, for enrichment at the $G_{1} / S$ border before they were returned to drugfree complete medium to enter $\mathrm{S}$ phase. The synchronization procedure used is represented in Fig. 2. The synchronized cells were monitored by flow-cytometric analysis using Hoechst 33342 for DNA staining, and their DNA profiles are shown in Figure 3A. Thus, serum-starved cells that were re-fed with complete medium for 4 hours were considered as $G_{1}$ cells, possibly as late $G_{1}$ cells because the doubling time of HD11 cells is less than 24 hours under optimal culture conditions. Most $G_{0}$ and $G_{1}$ cells as well as aphidicolin-synchronized cells at the $G_{1} / S$ border contain a $2 \mathrm{n}$ DNA amount, although aphidicolin has been shown to be an inhibitor of the chain elongation of DNA replication and arrests cells after the establishment of replication forks (Dijkwel and Hamlin, 1992; Levenson and Hamlin, 1993). Moreover, the reagent is not able to inhibit DNA polymerase $\gamma$ which is essential for the synthesis of mitochondrial DNA (Ikegami et al., 1978). S cells, 3 hours after removal of aphidicolin, display a DNA content of $2 \mathrm{n}$ to $4 \mathrm{n}$. Cells synchronized by this protocol using aphidicolin were then subjected to partial digestion with 250 units/ml DNase I as described above. An analysis of the chromatin structure of the OBR/GAS41 promoter region is shown in Figure $3 \mathrm{~B}$. It is apparent that the overall sensitivity to DNase I of the chromatin of this region increased in cells arrested in $G_{1}$ phase in comparison to the nuclease sensitivity in serum-starved $\mathrm{G}_{0}$ cells or of cells collected from $S$ phase and at the $G_{1} / S$ border. Accordingly, the intensity of the $3.3-\mathrm{kb}$ DNA band that corresponded to the HindIII fragment $(\mathrm{H} 9-\mathrm{H} 1 \mathrm{O})$ containing the OBR and the GAS41 promoter was markedly reduced. Thus, the nuclease sensitivity in synchronized cells decreased in the following order, $\mathrm{G}_{1}>\mathrm{G}_{1} / \mathrm{S}>\mathrm{S}>\mathrm{G}_{0}$. Figure $3 \mathrm{~B}$ shows further that the HS sites became much more sensitive in G1 phase and at the $G_{1} / S$ border than in $S$ and $G_{0}$ phases. To test whether the cell-cycledependent high DNase I sensitivity is restricted to the region surrounding the OBR and the GAS41 promoter, a Southern blot was hybridized to probe H11- H12 (see map in Fig. 1A) to analyze the region located downstream of the OBR. As seen in Figure 3C, we found no major differences in intensity of the diagnostic DNA band H11-H12 during the cell cycle. 


\section{A}

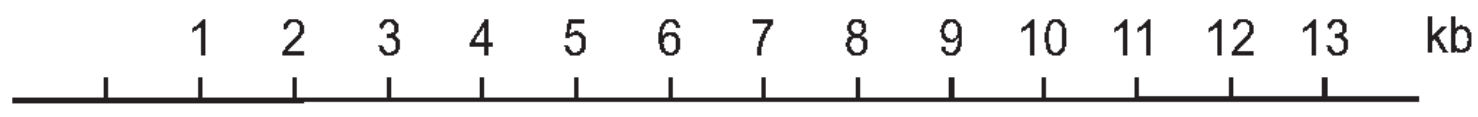

OBR
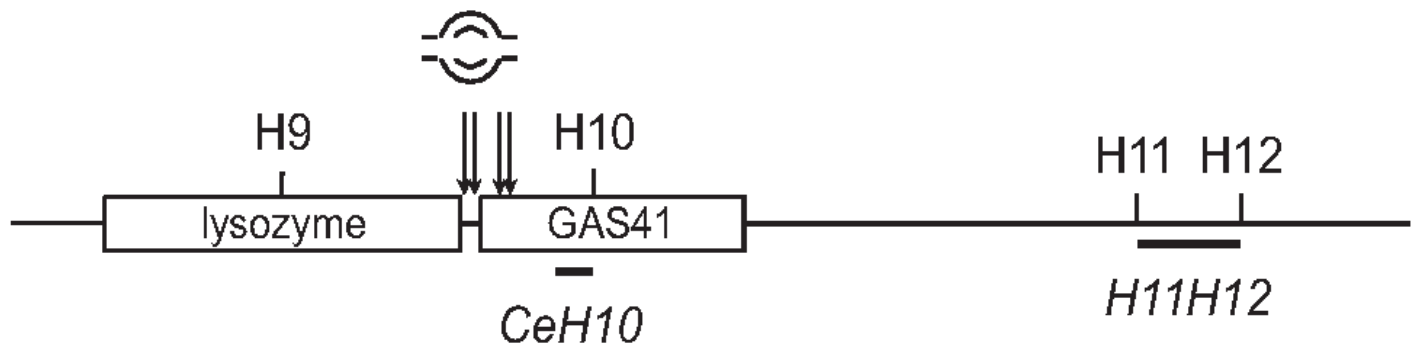

$\mathrm{B}$
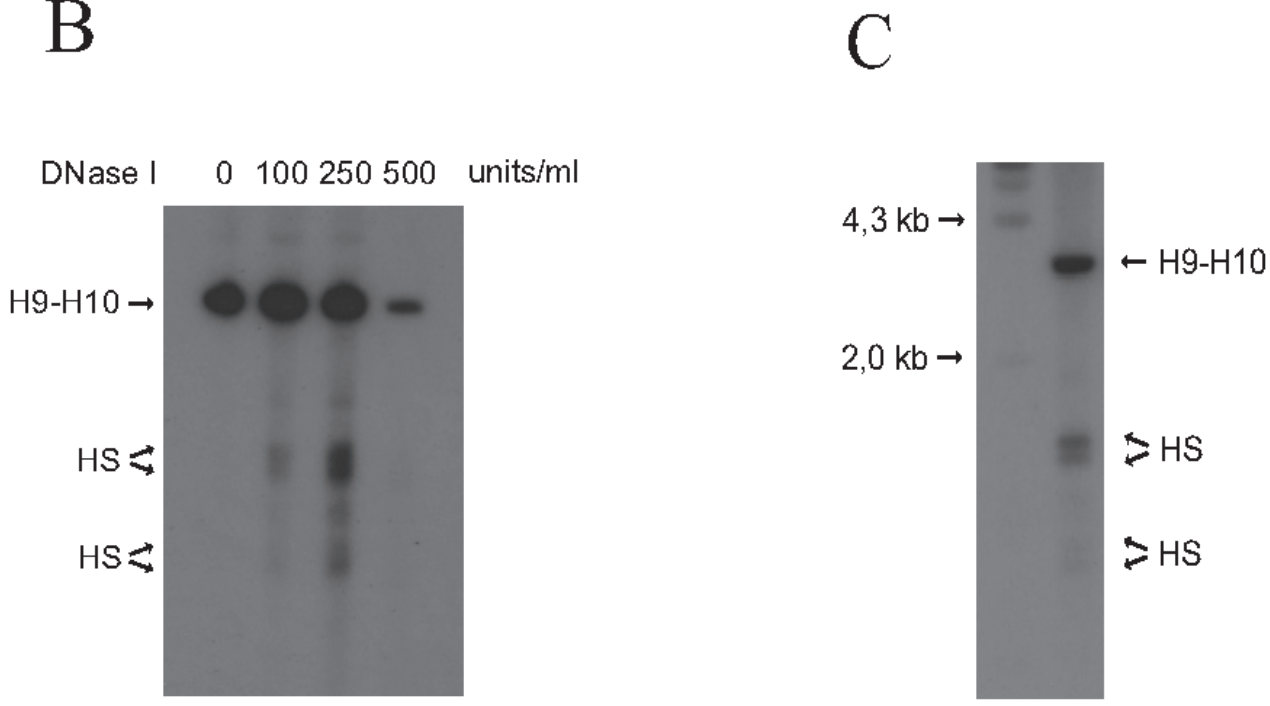

Figure 1: Mapping of HS sites in the OBR/GAS41 promoter region. (A) Schematic map of the lysozyme-GAS41 locus showing the restriction sites. H9, H10, H11 and H12 indicate HindIII sites 9, 10, 11 and 12. The major HS sites are indicated by vertical arrows. (B) HD11 cells permeabilized by lysolecithin were incubated with increasing concentrations of DNase I. DNA was then purified and digested with HindIII. Digested DNA samples were electrophoretically resolved on a $1.2 \%$ agarose gel and blotted on a nylon membrane. The blot was then hybridized to probe $\mathrm{CeH} 10$. Marker sizes are noted on the right-hand side. (C) Nuclei isolated from HD11 cells were digested with DNase I at the concentration of 150 units per $\mathrm{ml}$, and the HS sites were mapped using probe $\mathrm{CeH} 10$ as described above. Marker fragments shown are HindIII-digested $\lambda$ DNA. 


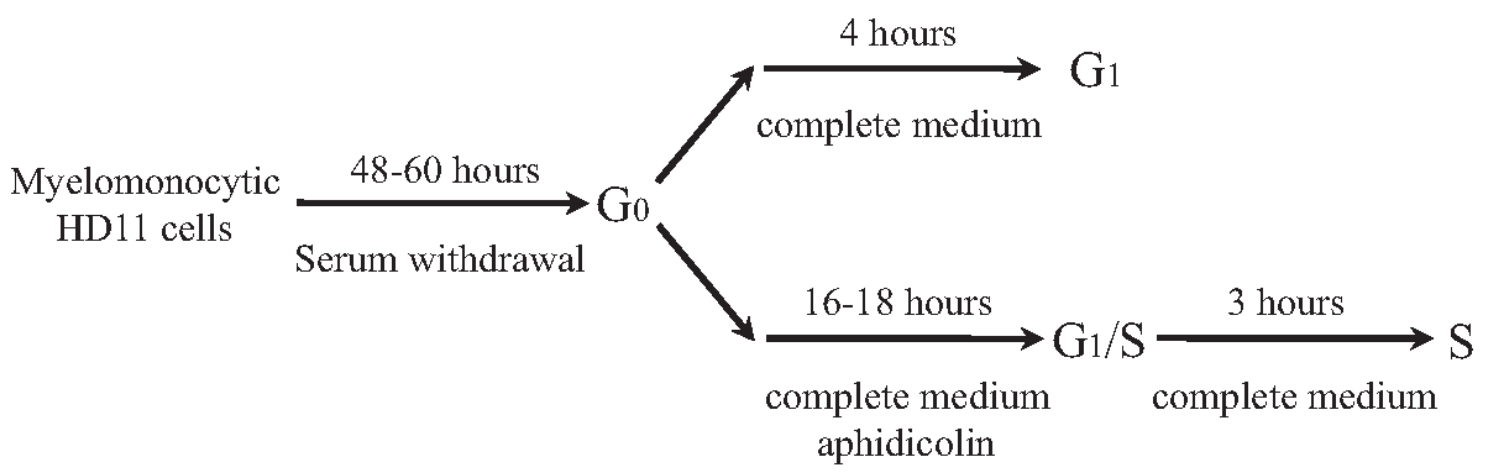

Figure 2: Schematic representation of the synchronization of chicken myelomonocytic HD11 cells. The synchronization of HD11 cells were performed as described in Methods.

\section{DISCUSSION}

Eukaryotic genomes are packaged together with histones and non-histone proteins into chromatin. The accessibility of chromatin in the interphase to nuclear factors is restricted to nucleosome-free regions, so called HS sites which play important roles in regulating cellular processes such as transcription and DNA replication. The identification of $\mathrm{HS}$ sites using isolated nuclei is time-consuming. Furthermore, given that nuclei are usually prepared biochemically using different buffer systems including detergents such as triton $\mathrm{X}-100$, the possibility that the physiological chromatin structure is disturbed by rearrangement or loss of DNA-binding proteins during the preparation, cannot be excluded. To avoid this problem, and in spite of the fact that the chromatin is not static, but dynamic by relevant DNAprotein interactions, it is necessary that experiments studying transient chromatin changes are done on intact cells. Therefore, in this work, we used lysolecithin to partially permeabilize the cell before digestion with DNase I. The use of lysolecithin for in vivo footprinting studies has been already reported (Pfeifer and Riggs, 1991). The HS sites detected by the described procedure are very similar to those generated from experiments using isolated nuclei. Furthermore, results obtained from our study demonstrated that the protocol used was not only fast and simple, but also useful for studying dynamic chromatin in vivo. Here, we observed changes in the chromatin at the OBR and GAS41 promoter during the cell cycle. The DNase I sensitivity of the region was higher in $G_{1}$ phase than in the other phases. Accordingly, the accessibility of the chromatin to nuclear factors seems to be higher in this phase. Because the OBR comaps largely with the GAS41 promoter, we cannot exclude the possibility that the observed chromatin changes in $\mathrm{G}_{1}$ phase are related to the transcriptional activity of the GAS41 promoter. If this is the case, one would expect a higher expression of the GAS41 gene in $G_{1}$ phase than in the other phases. However, using Northern blot procedure for analysis of RNA from synchronized cells, no differences in GAS41 mRNA expression were detected during the cell cycle (data not shown). Therefore, it remains possible that the chromatin changes observed in this study are related to a functional role in DNA replication.

Cell cycle-dependent disturbances in chromatin structure at origins of DNA replication have been reported. These chromatin changes are correlated with the respective accessibility to nucleases. For example, the DNAse I sensitivity of the histone $\mathrm{H} 3 / \mathrm{H} 4$ autonomously replicating sequence (ARS) element of the yeast Saccharomyces cerevisiae is higher in $\mathrm{S}$ phase than in pre-replicative phases of the cell cycle (Brown et al., 1991). On the other hand, in Chinese hamster ovary CHOC 400 cells synchronized with mimosine, an 
A

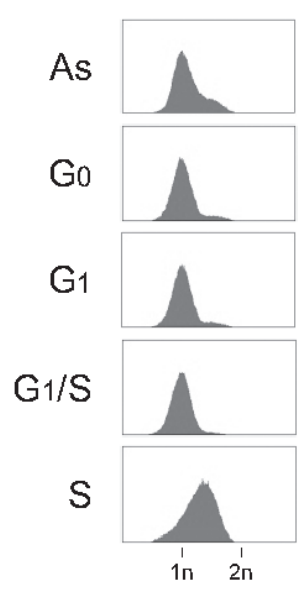

$\mathrm{B}$

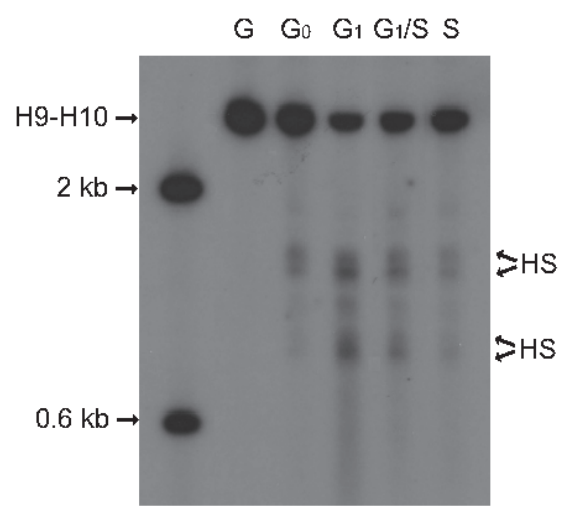

$\mathrm{C}$

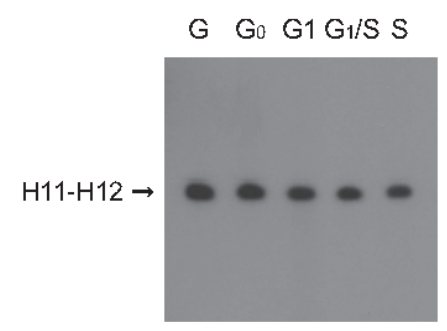

Figure 3: Cell cycle-dependent DNase I accessibility at the OBR. (A) flow cytometric analysis of asynchronous cells (As), quiescent cells $\left(G_{0}\right)$, G1 cells $\left(G_{1}\right)$, cells at the $G_{1} / S$ border $\left(G_{1} / S\right)$ and $S$ cells (S) stained with Hoechst 33342. (B) and (C), synchronized HD11 cells were permeabilized by lysolecithin and digested with 250 units/ml DNase I. DNA was isolated, digested with HindIII and analyzed by Southern blot hybridization using probes $\mathrm{CeH} 10$ and $\mathrm{HI1}-\mathrm{H} 12$ as described above. For control, genomic DNA digested with HindIII was used (G). 
inhibitor of cell cycle progression in late $\mathrm{G}_{1}$ phase (Lalande, 1990; Hoffman et al., $1991)$, the chromatin in the ori- $\beta$ and ori- $\gamma$ of the dihydrofolate reductase locus undergoes dramatic alterations in nuclease hypersensitivity (Pemov et al., 1998). Increasing evidence indicates that chromatin remodeling is essential for increased accessibility of nucleosomal DNA to transcription and DNA replication factors (Narlikar et al., 2002; Bozhenok et al., 2002; reviewed by Becker and Horz, 2002). Indeed, recent studies using synchronized cells suggest that cell cycle changes in chromatin by nucleosome remodeling at origins in the $G_{1}$ phase are important steps involved in controlling replication initiation and replication timing in eukaryotic cells (Zhou et al.,2005; Li et al., 2005). At present we do not know about the exact molecular mechanism of the cell cycle-dependent chromatin changes observed in this study. Whether the increased chromatin accessibility to nucleases at the OBR and GAS41 promoter in $\mathrm{G}_{1}$ cells is caused by nucleosome remodeling, we will investigate in a further study.

\section{ACKNOWLEDGMENTS}

We thank Dr. J. Kjaer for critical reading of the manuscript. This work was supported by the "Deutsche Forschungsgemeinschaft" (Ph 52/3-2).

\section{REFERENCES}

BECKER PB, HORZ W (2002) ATP-dependent nucleosome remodelling. Annu Rev Biochem 71: 247273

BEUG H, VON KIRCHBACH A, DÖDERLEIN G, CONSCIENCE J-F, GRAF T (1979) Chicken hematopoietic cells transformed by seven strains of defective avian leukemia viruses display three distinct phenotypes of differentiation. Cell 18: 375-390

BOZHENOK L, WADE PA, VARGA-WEISZ P (2002) WSTF-ISWI chromatin remodelling complex targets heterochromatic replication foci. EMBO J 21: 22312241

BROWN JA, HOLMES SG, SMITH MM (1991) The chromatin structures of Saccharomyces cerevisiae autonomously replicating sequences changes during the cell division cycle. Mol Cell Biol 11: 5301-5311

DIJKWEL PA, HAMLIN JL (1992) Initiation of DNA replication in the dihydrofolate reductase locus is confined to the early $\mathrm{S}$ period in $\mathrm{CHO}$ cells synchronized with the plant amino acid mimosine. Mol Cell Biol 12: 3715-3722

ELGIN SCR (1995) Chromatin structure and gene expression. Oxford University Press, New York

ELGIN SCR (1988) The formation and function of DNase I hypersensitive sites in the process of gene activation. $\mathrm{J}$ Biol Chem 263: 19259-19262

FRITTON HP, IGO-KEMENES T, NOWOCK J, STRECHJURK U, THEISEN M, SIPPEL AE (1987) DNase Ihypersensitive sites in the chromatin structure of the lysozyme gene in steroid hormone target and nontarget cells. Biol Chem Hoppe-Seyler 368: 111-119

HEWISH DR, BURGOYNE LA (1973) Chromatin substructure. The digestion of chromatin DNA at regularly spaced sites by a nuclear deoxyribonuclease. Biochem Biophys Res Commun 52: 504-510

HOFFMAN BD, HANAUSKA-ABEL HM, FLINT A, LALANDE M (1991) A new class of reversible cell cycle inhibitors. Cytometry 12: 26-32

IKEGAMI S, TAGUCHI T, OHASHI M, OGURO M, NAGANO H, MANO Y (1978) Aphidicolin prevents mitotic cell division by interfering with the activity of DNA polymerase-alpha. Nature 275: 458-460

JÄGLE U, MÜLLER AM, KOHLER H, BONIFER C (1997) Role of positive and negative cis-regulatory elements in the transcriptional activation of the lysozyme locus in developing macrophases of transgenic mice. J Biol Chem 272: 5871-5879

LALANDE M (1990) A reversible arrest point in the late G1 phase of the mammalian cell cycle. Exp Cell Res 186: $332-339$

LEVENSON V, HAMLIN JL (1993) A general protocol for evaluating the specific effects of DNA replication inhibitors. Nucleic Acids Res 21: 3997-4004

LI J, SANTORO R, KOBERMA K, GRUMMT I (2005) The chromatin remodeling complex NoRC controls replication timing of rRNA genes. EMBO J 24: 120127

NARLIKAR GJ, FAN HY, KLINGSTON RE (2002) Cooperation between complexes that regulate chromatin structure and transcription. Cell 108: 475487

PEMOV A, BAVYKIN S, HAMLIN JL (1998) Attachment to the nuclear matrix mediates specific alterations in chromatin structure. Proc Natl Acad Sci USA 95: 14757-14762

PFEIFER GP, RIGGS AD (1991) Chromatin differences between active and inactive $\mathrm{X}$ chromosomes revealed by genomic footprinting of permeabilized cells using DNase I and ligation-mediated PCR. Genes Dev 5: 1102-1113

PHI-VAN L, SELLKE C, VON BODENHAUSEN A, STRÄTLING WH (1998) An initiation zone of chromosomal DNA replication at the chicken lysozyme gene locus. J Biol Chem 273: 18300-18307

PHI-VAN L, STRÄTLING WH (1999) An origin of bidirectional DNA replication is located within a $\mathrm{CpG}$ island at the 3' end of the chicken lysozyme gene. Nucleic Acids Res 27: 3009-3017

SOUTHERN EM (1975) Detection of specific sequences among DNA fragments separated by gel electrophoresis. J Mol Biol 98: 503-517

STEINER C, MÜLLER M, BANIAHMAD A, RENKAWITZ R (1987) Lysozyme gene activity in chicken macrophages is controlled by positive and negative regulatory elements. Nucleic Acids Res 15: 4163-4179

WU C (1980) The 5' ends of Drosophila heat shock genes 
in chromatin are hypersensitive to DNase I. Nature 286: 854-860

ZHOU J, CHAU CM, DENG Z, SHIEKHATTAR R, SPINDLER MP, SCHEPERS A, LIEBERMAN PM (2005) Cell cycle regulation of chromatin at an origin of DNA replication. EMBO J 24: 1406-1417
ZIMMERMANN K, AHRENS $\mathrm{K}$, MATTHES S, BUERSTEDDE J-M, STRÄTLING WH, PHI-VAN L (2002) Targeted disruption of the GAS41 gene encoding a putative transcription factor indicates that GAS41 is essential for cell viability. J Biol Chem 277: 18626-18631 